\title{
A case study in spatial wood supply analysis
}

\author{
by G.A. Jordan ${ }^{1}$ and E.Z. Baskent ${ }^{2}$
}

This paper shows the effects of extraction economics and wildlife habitat values on wood supply for a 9,640 stand forest in New Brunswick. Using a spatial wood supply model developed at the University of New Brunswick, the paper quantifies and explains wood supply effects of harvest blocking, road cost and harvest adjacency delay. Eight spatial strategies test harvest scheduling based on geographic forest structure (distribution of stand developmental types and stages). Given a forest of mostly regenerating and mature developmental stages, wood supply reductions vary from $4.9 \%$ to $19.2 \%$ when compared to a convention aspatial assessment. The paper presents and explains reductions for all eight spatial strategies; but concludes that all are explained by the impacts that harvest blocking, road cost, or harvest adjacency delay have, singly, or in combination, on either mortality losses or the rate at which harvesting recycles forest area.

Key words: Forest management, forest dynamics, GIS, wildlife, simulation, wood supply, harvest scheduling

\section{Introduction}

Wood supply has been the focus of much interest and effort in Canada throughout the 1980's. Faced with impending wood shortages in many regions of the country, forestry organisations and professional foresters have struggled to develop appropriate forest management strategies. Finding traditional rules and approaches for calculation of AAC totally inadequate in recognizing the dynamic nature of forest development under management, Baskerville (1978), Clifford (1981) and Hall $(1978,1981)$ pioneered an alternative simulation modelling approach. Models, such as FORMAN (Wang et al. 1987) and its many imitators, were an outgrowth of this early work. The models share a simple inventory projection approach. They forecast growing stock $\left(\mathrm{m}^{3}\right)$ by tracking forest strata $^{3}$ according to volume development over time as a specified intervention strategy and is applied in a controlled and measured manner across a model forest.

Wood supply models have proven useful for many Canadian forestry organisations in forest management planning. By linking forest change over time to harvest and silviculture scheduling, models permit forest managers to forecast and compare effects of different management design strategies on a forest's wood supply. While the various models now in use differ greatly in the specific intervention rules available for management strategy formation, all typically provide some measure of control over the types, amounts

\footnotetext{
'Professor in the Faculty of Forestry, University of New Brunswick, BSN 44555, Fredericton, New Brunswick E3B 6C2.

${ }^{2}$ Research Assistant in the Faculty of Forestry, Karadeniz Technical University, Trabzon, Turkey. Currently a graduate student at the University of New Brunswick, Fredericton, NB.
}

Cet article fait état des effets de l'extraction de la matière ligneuse sur les valeurs en termes économiques et d'habitats fauniques à partir d'un peuplement forestier de 9640 ha. au NouveauBrunswick. Utilisant un modèle d'approvisionnement spatial en matière ligneuse mis au point par l'Université du NouveauBrunswick, cet article quantifie et explique les effets sur l'approvisionnement en matière ligneuse, à partir du compartimentage de la récolte, des coûts des chemins et du délai de coupe dans les blocs adjacents. Huit stratégies spatiales ont été testées à partir d'une planification de récolte basée sur la structure géographique de la forêt (distribution selon le type et le stade de développement des peuplements). A partir d'une forêt principalement au stade de régénération et de maturité, les réductions de l'approvisionnement en matière ligneuse variaient de $4.9 \%$ à $19.2 \%$ lorsque comparé à une évaluation conventionnelle sans référence spatiale. Cet article présente et explique les réductions obtenues pour les huit stratégies spatiales, mais conclut que toutes sont expliquées par les impacts sur le compartimentage de la récolte, les coûts des chemins, ou du délai de coupe dans les blocs adjacents qui ont, individuellement, ou en association, un effet soit sur les pertes dûes par mortalité soit sur le taux selon lequel la récolte permet de régénérer la superficie forestière.

Mots Clés: Aménagement forestier, dynamique forestière, SIRS, faune, simulation, approvisionnement en matière ligneuse, planification de la récolte

and timings of harvesting and silviculture. For a given strategy, the models forecast a forest's operable ${ }^{4}$ growing stock and translate the strategy into a harvest and silviculture schedule for implementation. In the course of a wood supply analysis, forest managers usually formulate and test dozens of strategies for effect on sustainable wood supply.

Unfortunately, an aspatial approach that lacks location specific resolution afflicts wood supply models developed in the 1980 's. Modelling and forecasting is limited to the numeric, aspatial distribution of a forest's stand developmental types and stages. Lacking a means to control the locations of interventions, contemporary models are limited to aspatial harvest and silviculture strategies and the production of aspatial forest response indicators and implementation schedules that do not reflect on-the-ground operational realities. Consequently, they provide a flawed assessment of wood supply. While contemporary models are sufficient for defining and developing aspatial management design strategies for wood supply, they lack consideration of the geographic structure of forests and are insufficient for design of wildlife sensitive and economically acceptable management.

A recently developed model (Baskent 1990) considers both numeric and geographic forest structure in wood supply modelling, i.e., a spatial model. The model, called GISFORMAN (Geographic Information System linked FORest MANagement), permits assessment of wood supply based upon timber extraction economics (harvest blocking,

\footnotetext{
${ }^{3} \mathrm{~A}$ stratum is an aggragete of forest stands which have at least age, current condition (e.g., volume, species mix) and pattern of future development in common.

${ }^{4}$ Operable volume is the economically harvestable portion of merchantable stand volume determined by piece size and $\mathrm{m}^{3} / \mathrm{ha}$.
} 


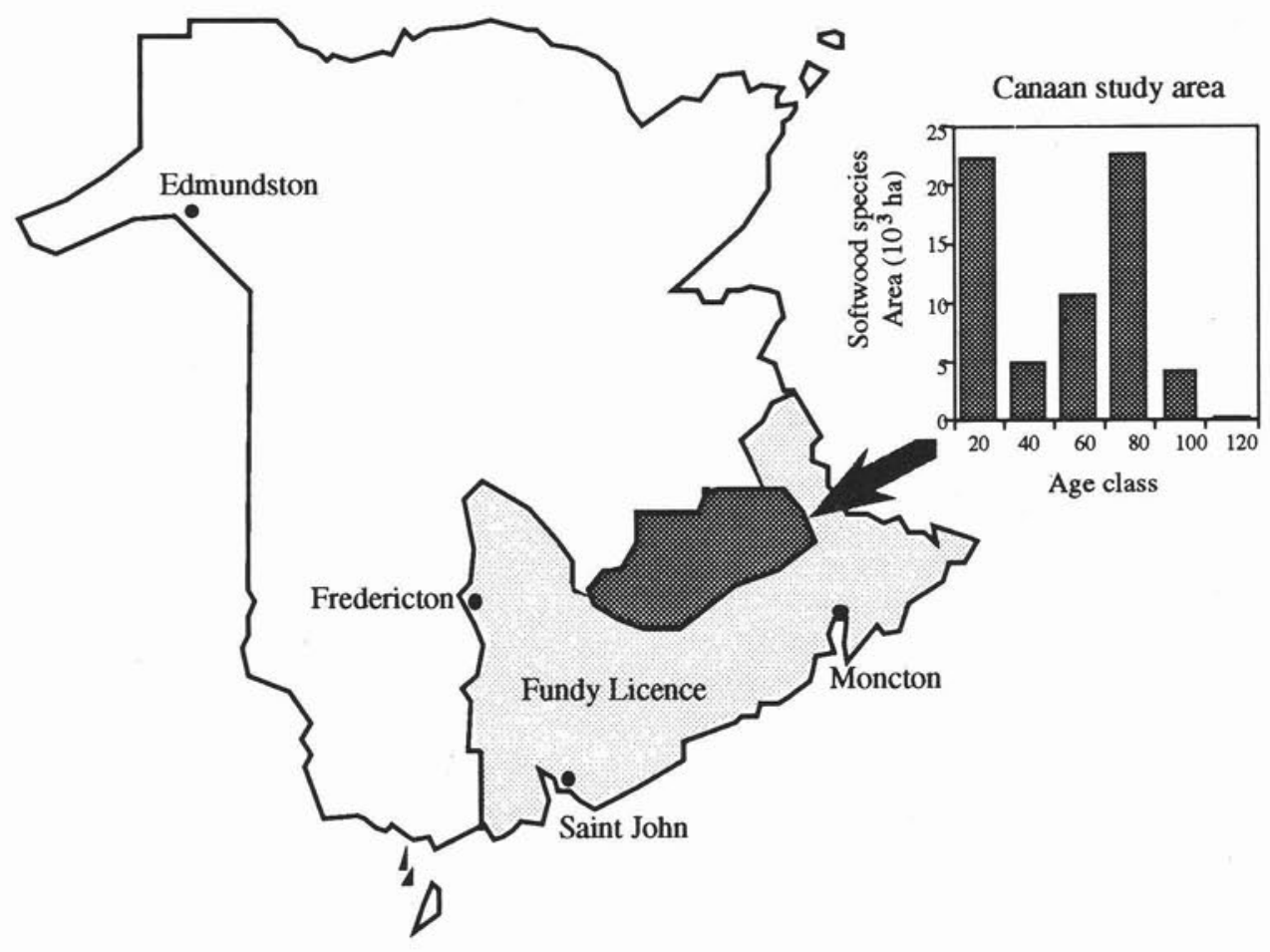

Figure 1. A map of the Canaan forest in east central New Brunswick.

operating road $\operatorname{cost}^{5}$ ) and wildlife habitat values (harvest opening size, adjacency delay ${ }^{6}$ ). By using geographic structure to control harvest scheduling, the model can forecast an economic, unconstrained growing stock for a subject forest. Baskent and Jordan (1990) described in detail GISFORMAN's design, programming and operating characteristics. This paper presents and discusses the results of a case study application of GISFORMAN that sought to identify, quantify and explain some effects of wildlife sensitive and economically acceptable management strategies on sustainable wood supply.

\section{Case Study}

The Canaan wood supply area, a portion of a New Brunswick Crown Licence managed by J.D. Irving Ltd., was selected for the case study. The area covers 111,296 ha, of which 72,526 ha are productive forest, in east-central New Brunswick (Figure 1). The area has 15,975 stands, of which 9,640 are productive, and 26 provincial forest covertype maps cover the area. The age class distribution of primary species developmental types (softwoods) is typical of most areas in New Brunswick: unbalanced with most of the forest in regenerating and mature developmental stages.

\section{Model Input}

The provincial database of covertype maps (ARC/INFO coverages) provided basic forest inventory consisting of stand

\footnotetext{
${ }^{5}$ Operating road refers to the temporary road network within a harvest block. Cost is calculated as a function of road length and operable block volume (Baskent and Jordan 1990).

${ }^{6} \mathrm{An}$ adjacency delay is a wildlife habitat consideration that specifies a time delay between harvest of adjacent areas.
}

attributes, locations and topology ${ }^{7}$. The covertype coverages, provided by the Timber Management Branch (TMB) of the Department of Natural Resources and Energy (DNR), supplied the data required by the CALCADJ program (Baskent and Jordan 1990) to create a harvest block configuration file, with 10 ha minimum and 125 ha maximum contiguous blocks. Fixed input data to the model assumed $\$ 6,250 / \mathrm{km}$ operating road construction cost and 30 ha of forest accessed by one kilometre of operating road (pers. comm. Brunsdon ${ }^{8}$ 1990). Additionally, $\$ 3,000$ was assumed to be the partial fixed access cost (overhead associated with moving equipment and personnel) for any harvest block).

J.D. Irving Ltd. staff provided volume yield curve data. A total of 109 yield curve sets were identified for the Canaan area in 1987 management plan preparation and were used in this study as well. The yield curve data included primary (softwood) and secondary (hardwood) merchantable volumes and operability limits (ages) for each forest stratum. Each curve set also identified intervention response curves. Stands planted, spaced or harvested would follow these. GISFORMAN requires stand-by-stand data, and therefore, it was not possible to use directly the 1987 volume yield data assembled for strata. Several INFO DBMS programs were written specifically for the Canaan study area to assign present, harvest, plant and regeneration response curves to each stand (Baskent 1990).

\footnotetext{
${ }^{7}$ Topology refers to the spatial relationship of map features, i.e. what's next to what.

${ }^{8}$ Blake Brunsdon, Chief Forester, J.D. Irving Ltd. Saint John, NB.
} 
Table 1. Summary of the strategies tested and their sustainable harvest results

\begin{tabular}{|c|c|c|c|c|c|}
\hline$\underset{\#}{\dagger \text { Strategy }}$ & $\begin{array}{c}\text { Harvest } \\
\text { rule }\end{array}$ & $\begin{array}{c}\text { Operating } \\
\text { road cost } \\
\left(\$ / \mathrm{m}^{3}\right)\end{array}$ & $\begin{array}{c}\text { Adjacency } \\
\text { delay } \\
\text { (\# of periods) }\end{array}$ & $\begin{array}{c}\text { Sustained } \\
\text { harvest level } \\
\left(\mathrm{m}^{3} / \text { year }\right)\end{array}$ & $\begin{array}{c}\text { Harvest reduction } \\
\text { versus control } \\
(\%)\end{array}$ \\
\hline Control & 1 & - & - & 102000 & - \\
\hline 1 & $\min$ road cost & - & 1 & 97000 & 4.9 \\
\hline 2 & " & - & 2 & 85700 & 15.9 \\
\hline 3 & " & 15 & 1 & 93200 & 8.6 \\
\hline 4 & " & 15 & 2 & 82800 & 18.8 \\
\hline 5 & min mortality & - & 1 & 94000 & 7.8 \\
\hline 6 & " & - & 2 & 84000 & 17.6 \\
\hline 7 & " & 15 & $i$ & 91000 & 10.7 \\
\hline 8 & " & 15 & 2 & 82400 & 19.2 \\
\hline
\end{tabular}

$†$ minimum and maximum block sizes were 10 and 125 ha respectively for all strategies

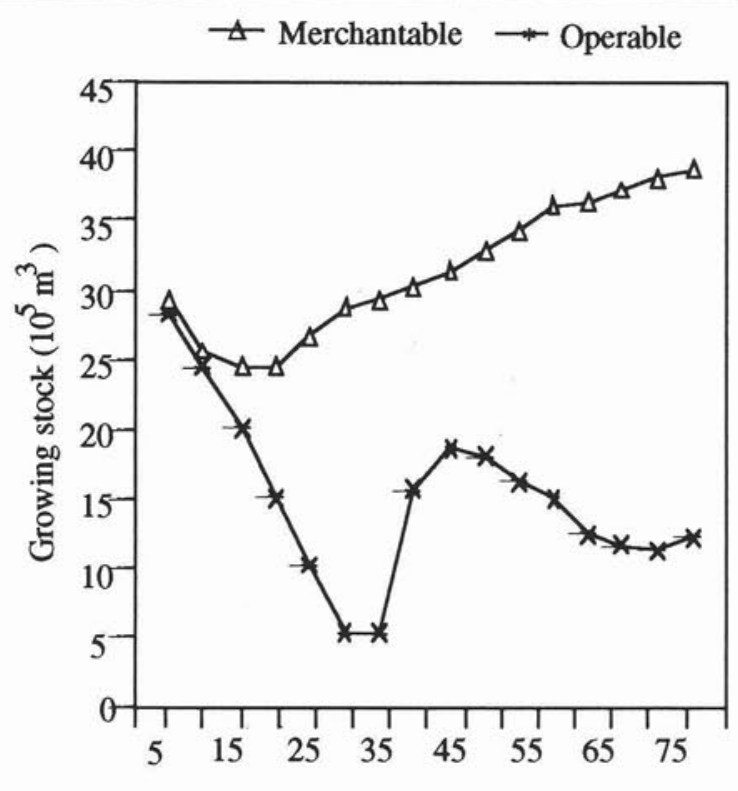

Time in future (years)

(a)

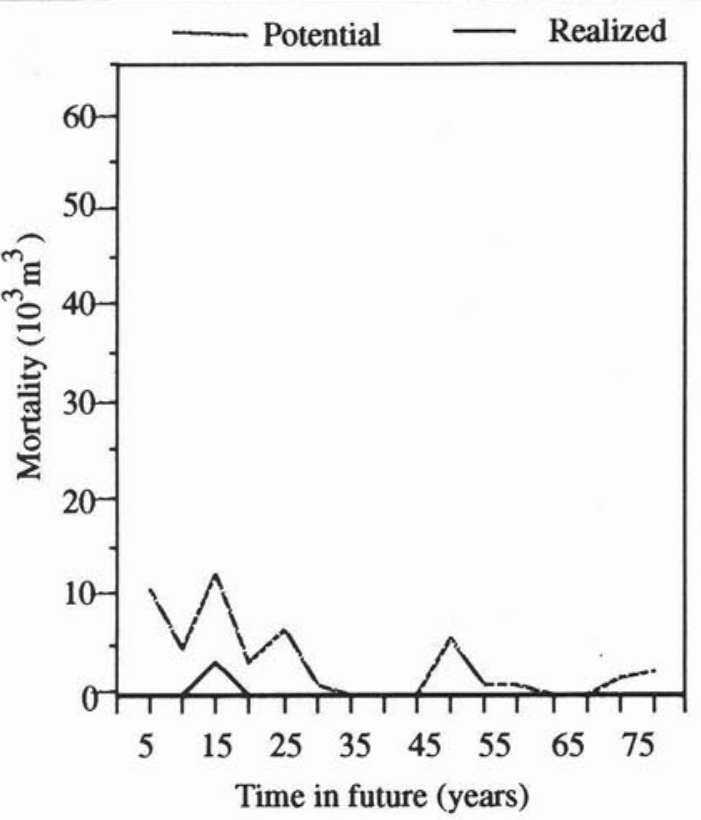

(b)

Figure 2. The results of the Control strategy (minimize stand mortality, no spatial constraints). Sustained harvest level is $510000 \mathrm{~m}^{3} /$ period. The performance indicators are: (a) growing stock (b) primary volume loss.

\section{Wood Supply Analysis}

Several management strategies were chosen to help quantify and explain the effects of wildlife sensitive and economically acceptable management strategies on sustainable wood supply. Among many possibilities, a total of eight strategies were used. They incorporated minimization of operating road cost (GISFORMAN Rule 8) or mortality loss (GISFORMAN Rule 10), with and without operating road cost limit and adjacency delay. An additional, aspatial, control strategy was used to establish a basis of comparison. This strategy neither incorporated harvest blocking, operating road cost limit, or adjacency delay nor produced geographically controlled harvest schedules. It merely used old FORMAN Rule 1 to minimize stand mortality losses. Rule 1, from among the other aspatial rules, was chosen since it was found in 1987 to be the harvesting rule that provided New Brunswick forest companies maximum sustainable harvest levels (pers. comm. Frame ${ }^{9}$ 1990). Consequently, the difference between the sustainable harvest level of any one of the eight spatial strategies and the control would reflect either the individual or combined wood supply effect of harvest blocking, minimizing operating road cost or mortality losses, and setting an operating road cost limit or adjacency delay.

Since the case study was not aimed at exploring the effect of geographic distribution of silvicultural treatments, each strategy to be tested used the same aspatial treatment specifications employed in 1987 planning: maximums of $300 \mathrm{ha} /$ year of planting and $700 \mathrm{ha} /$ year of spacing. Stands falling between ages 10 and 20 and having a spacing response curve were considered available for spacing.

The strategies tested consisted of four pairs that each shared common economic and wildlife constraints but employed different harvest rules (Strategies 1 and 5, 2 and 6,3 and 7, 4 and 8, as listed in Table 1). The first four strategies priorized blocks for harvest based on operating road cost

${ }^{9}$ Craig Frame, wood supply analyst for Crown Licences, Timber Management Branch Department of Natural Resources and Energy, NB. 
per cubic metre - least cost first. The remaining four strategies aimed at capturing block mortality losses. They priorized blocks for harvest based on their potential volume losses (5-year projected) due to mortality and, by harvesting blocks with largest losses first, aimed at achieving an actual, or realized, volume loss less than potential across a forest. Strategies 1 and 5 were designed to explore the impact of harvest blocking on sustainable harvest level without an operating road cost limit. However, the 125 ha block size constraint, that all strategies used, incorporated a de facto one period adjacency delay since any stand adjacent to a harvest block could not be harvested in the same period. Strategies 2 and 6 were the same except adjacency delay was extended an additional period. Strategies 3 and 7 were designed to restrict harvesting to blocks whose operating road cost per cubic metre was less than $\$ 15$. Finally, Strategies 4 and 8 were used to determine the sustainable harvest level effect of employing both a two period adjacency delay and a maximum operating road cost limit. Using the GISFORMAN model, harvest levels were tested in steps of $500 \mathrm{~m}^{3} /$ year to arrive at sustainable levels, i.e., no shortfalls for 80 years, for each strategy.

The results of the analysis (Table 1) permit a comparison of spatially and aspatially determined wood supplies for the Canaan study area, and an opportunity to isolate and quantify the effects of economic (harvest blocking, harvesting rule, operating road cost limit) and wildlife habitat (maximum block size and adjacency delay) considerations on sustainable wood supply.

\section{Harvest Blocking Effect}

Since all the strategies applied block-by-block harvesting, as opposed to stand or stratum, all produced a reduction in sustainable harvest level due to blocking. This reduction is, however, harvesting rule dependent. Strategy 1 and Strategy 5 produced $4.9 \%$ and $7.8 \%$ harvest reductions respectively (Table 1 ). These are attributable to blocking alone since neither an operating road cost limit nor a two period adjacency delay was involved. There are two main reasons that explain these reductions. First, when the model harvests a stand, its operable neighbours (contained within the block) are also harvested, despite their developmental stage. Therefore, some stands that have not reached peak volume are harvested before other stands that are in decline. Blocking sacrifices mortality losses (compare Fig. 3b and $7 \mathrm{~b}$ to Fig. $2 \mathrm{~b}$ ) and predictably results in a reduced sustainable harvest level. The difference in operable growing stock levels found in comparing Figures $3 \mathrm{a}$ and $7 \mathrm{a}$ to Figure $2 \mathrm{a}$ confirms this fact as well. Second, the maximum block size constraint limits harvesting, since it imposes a one period adjacency delay. The difference between operable and effective ${ }^{10}$ growing stocks found in Figure 3a and Figure 7a is a result of this. Additional reductions in sustainable harvest level, beyond those attributable to blocking, will depend upon the mix of constraints and harvest rules used in a management strategy.

\section{Minimizing Operating Road Cost Effect}

Results of Strategy 1, minimize operating road cost without an operating road cost limit, are depicted in Figure 3. The maximum sustainable harvest level is $97000 \mathrm{~m}^{3} /$ year - a $4.9 \%$ reduction from the control level. Besides the blocking effect explained previously, an additional reason for the $4.9 \%$ reduction is related to the harvest rule itself. Strategy 1 queued blocks based on operating road cost (cheapest first) as opposed to volume loss (greatest first). Thus, it left some mature stands to decline before harvest. The failure of the strategy to control mortality losses (Fig. 3b) resulted in the harvest level reduction.

Strategy 2, minimize operating road cost without an operating road cost limit but with adjacency delay extended an additional period, reduced the sustainable harvest level by $15.9 \%$ to $85700 \mathrm{~m}^{3} /$ year - an additional $11 \%$ $(15.9 \%-4.9 \%)$ reduction from Strategy 1 (Fig. 4). Besides the blocking effect and reasons provided for Strategy 1, the additional $11 \%$ reduction can be attributed to the extension in adjacency delay. In Strategy 2, any stand adjacent to a harvest block that was harvested in the previous period, in addition to any harvested in the current period, was not available for harvesting. Such stands were considered unavailable for harvest and did not contribute to effective growing stock, despite their state. Thus, significant differences occurred between operable and effective growing stocks (Fig. 4a), resulting in the additional $11 \%$ reduction in sustainable harvest level.

Strategy 3 , minimize operating road cost with a maximum operating road cost limit of $\$ 15$, reduced the sustainable harvest level by $8.6 \%$ to $83200 \mathrm{~m}^{3} /$ year - an additional $3.7 \%$ $(8.6 \%-4.9 \%)$ reduction from Strategy 1 (Fig. 5$)$. The additional reduction was due to the maximum $\$ 15$ operating road cost limit. Blocks exceeding the limit were considered unavailable for harvest and did not contribute to effective growing stock (Fig. 5a). However, the reduction was smaller than that of Strategy 2, implying, in this case, that the impact of extending adjacency delay an additional period is more constraining than a $\$ 15$ operating road cost limit.

Strategy 4 , minimize operating road cost with a maximum operating road cost limit of $\$ 15$ and two period adjacency delay, greatly reduced the harvest level by $18.8 \%$ to $82800 \mathrm{~m}^{3} /$ year, which is an additional $13.9 \%$ $(18.8 \%-4.9 \%)$ reduction from Strategy 1 (Fig. 6). The main reason for the reduction, besides the reasons provided for Strategy 1, is obvious. The combination of an extension in adjacency delay and a maximum $\$ 15$ operating road cost limit restricted more blocks from harvest. The large difference between operable and effective growing stocks (Fig. 6a) reflects this. It can be easily seen that a sharp increase in mortality, especially after the critical years (e.g., $54,000 \mathrm{~m}^{3}$ in Fig. 6b), occurs. This means that more blocks became inoperable and explains the reduced sustainable harvest level.

Performance indicators produced with Strategies 1 through 4 reflect the dynamics of the forest under management. Because of the broken age class structure of the Canaan forest, both operable and effective growing stock decreased rapidly in the first 30 years (Fig. 3a, 4a, 5a, and 6a). Years 25 to 35 were critical years since very few hectares became operable at this time. Figures $3 \mathrm{~d}$ and $4 \mathrm{~d}$ indicate that the average operating road cost dramatically increased during the critical years because minimizing operating road cost targeted most of the cheap forest for harvest before years 25

\footnotetext{
${ }^{10}$ Effective volume is the unconstrained portion of operable volume, i.e. the amount available for harvest given harvest blocks of limited size, operating road cost and/or adjacency delay limits.
} 


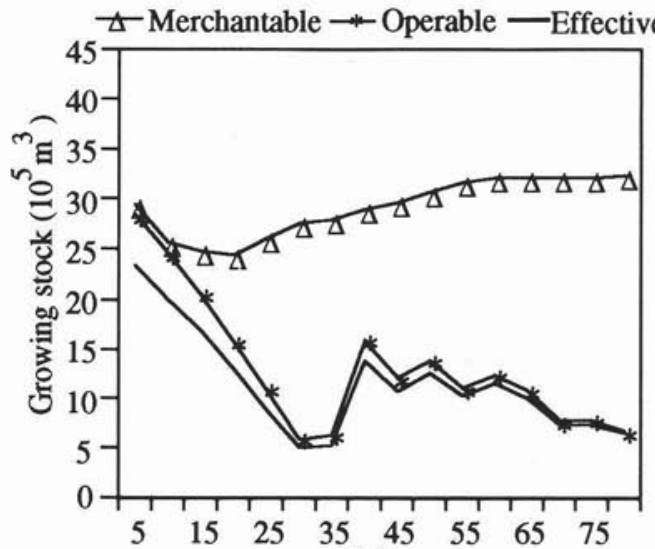

(a)

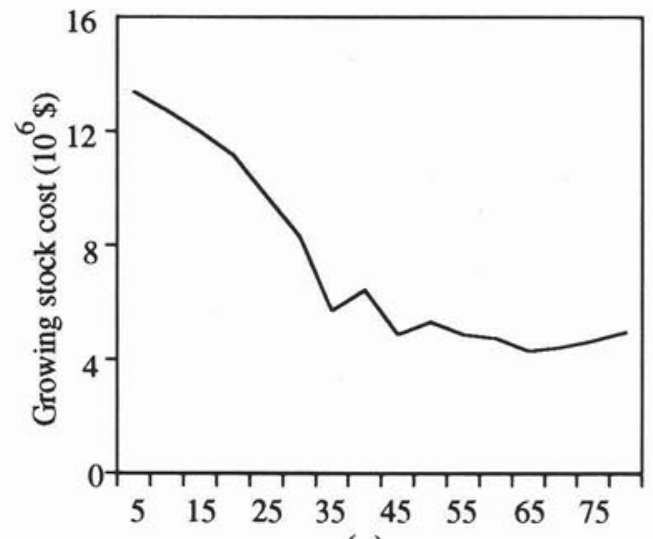

(c)

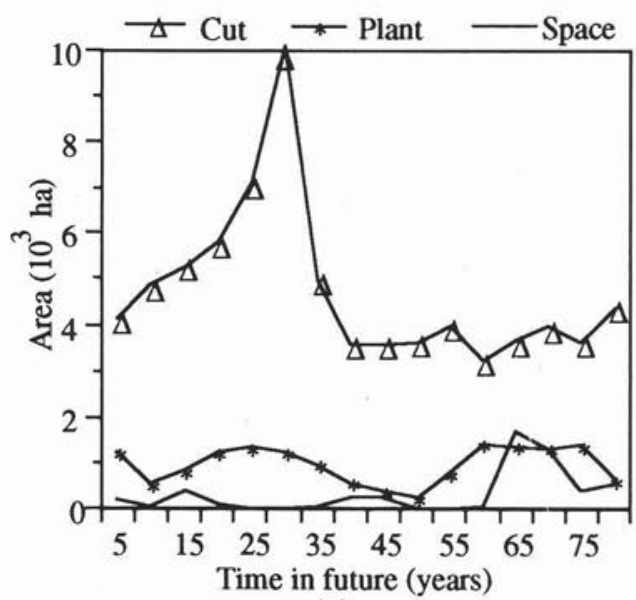

(e)

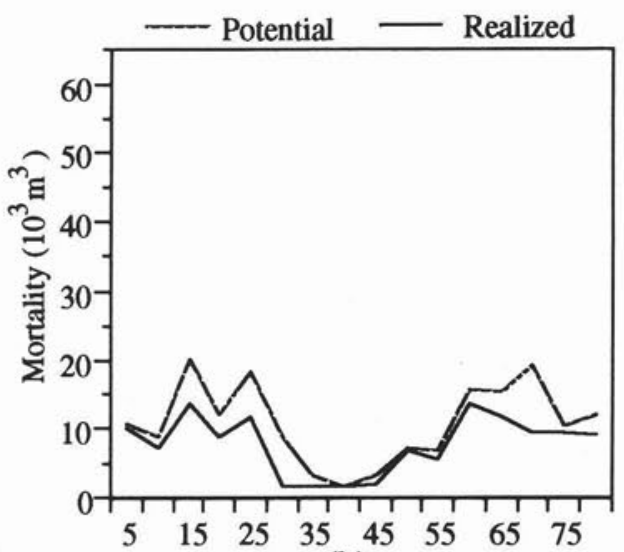

(b)

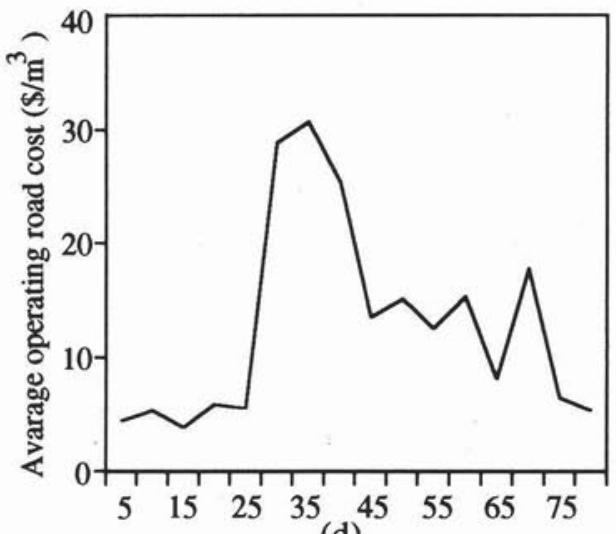

(d)

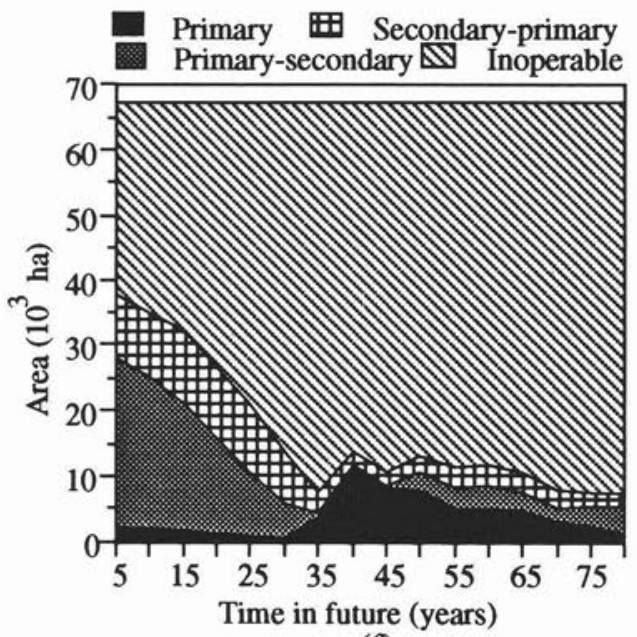

(f)

Figure 3. The results of Strategy 1 (minimize operating road cost, one period adjacency delay, no operating road cost limit). Sustained harvest level is $485000 \mathrm{~m}^{3} /$ period. The performance indicators are: (a) growing stock (b) mortality (c) growing stock cost (operating road) (d) average operating road cost (e) cut, planted and spaced area and (f) operable-inoperable area distribution.

to 35 , thus leaving more expensive stands to be harvested later. Because of the operating road cost limit in Strategies 3 and 4 , the average operating road cost, however, stayed almost constant (Figs. 5d and 6d) compared to Strategies 1 and 2 . Since few, scattered stands having less $\mathrm{m}^{3} /$ ha were left to be harvested during the critical years with all four strategies, a rapid increase in the area cut (Fig. 3e, 4e, 5e and $6 \mathrm{e}$ ) and decrease in the operable area (Fig. $3 \mathrm{f}, 4 \mathrm{f}, 5 \mathrm{f}$ and $6 \mathrm{f}$ ) occurred. After the critical years, the initial $0-20$ age class containing many hectares became available 


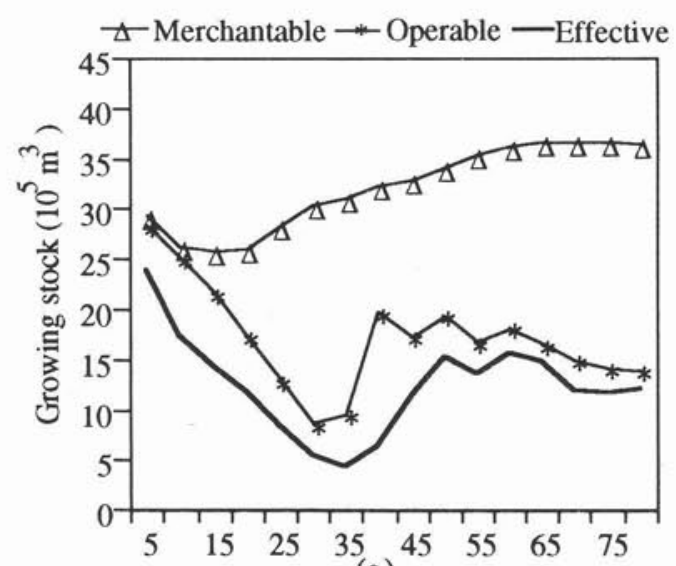

(a)
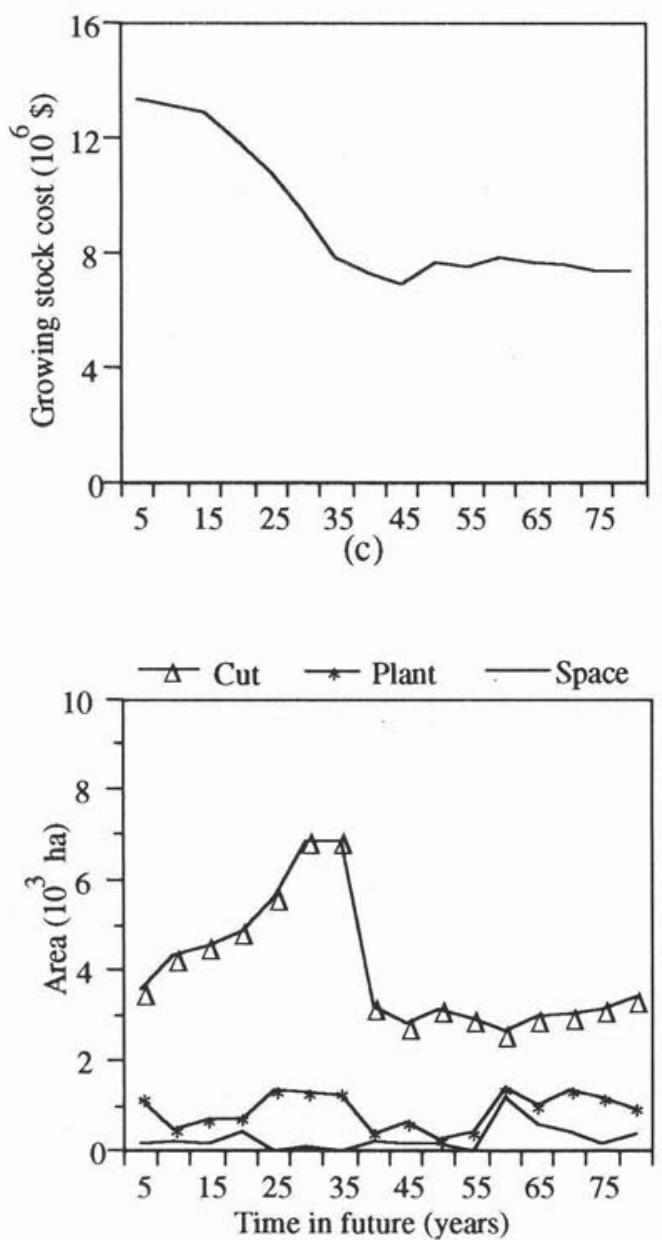

(e)

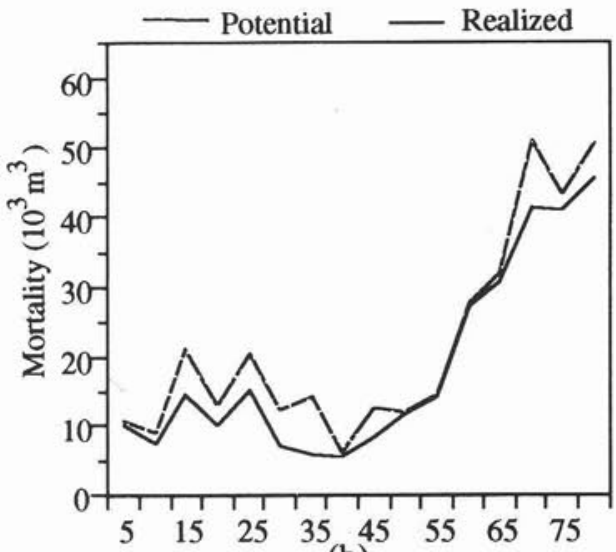

(b)

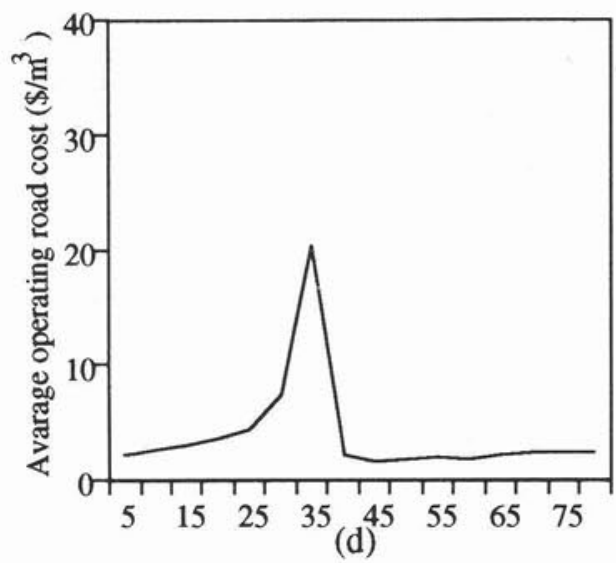

Primary 囿 Secondary-primary Primary-secondary $\mathbb{Q}$ Inoperable

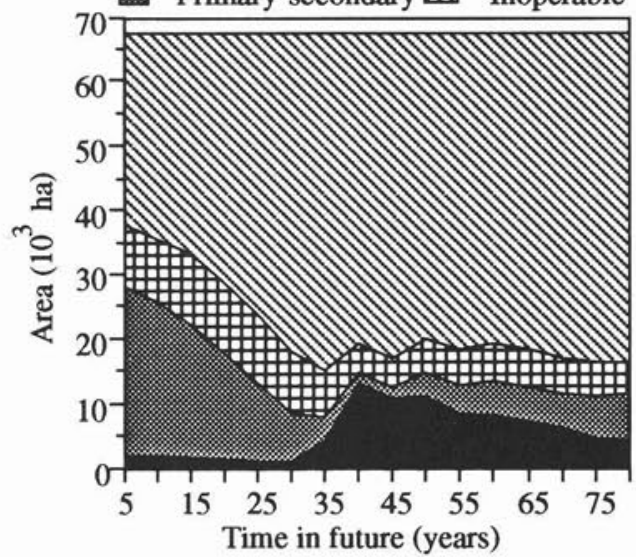

(f)

Figure 4. The results of Strategy 2 (minimize operating road cost, two period adjacency delay, no operating road cost limit). Sustained harvest level is $428500 \mathrm{~m}^{3} /$ period. The performance indicators are: (a) growing stock (b) mortality (c) growing stock cost (operating road) (d) average operating road cost (e) cut, planted and spaced area and (f) operable-inoperable area distribution.

for harvesting. Thus the operable and effective road cost and area cut decreased. However, although many hectares moved into the mature development stage after $35-40$ years, the operable area decreased with all the strategies tested for the study area. This was because some harvested stands converted to inoperable secondary volume, thus decreasing operable and effective growing stock and operable area as well.

As a result of operating road cost testing, two common observations can be made about the first four strategies. First, the strategies concentrated harvest mostly in geographic areas 


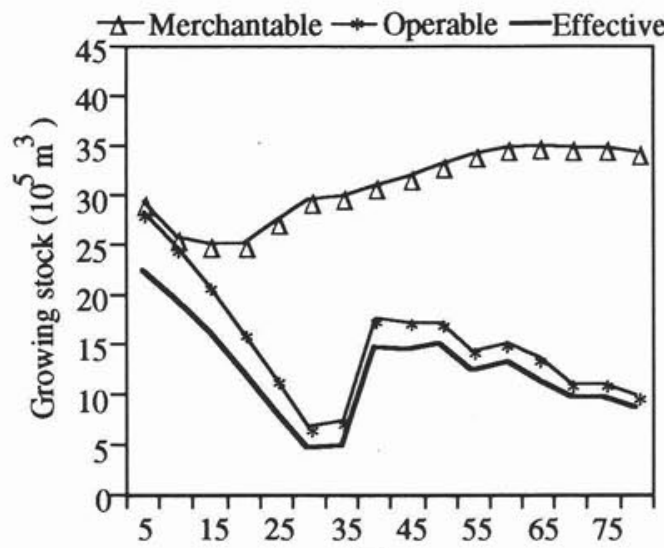

(a)

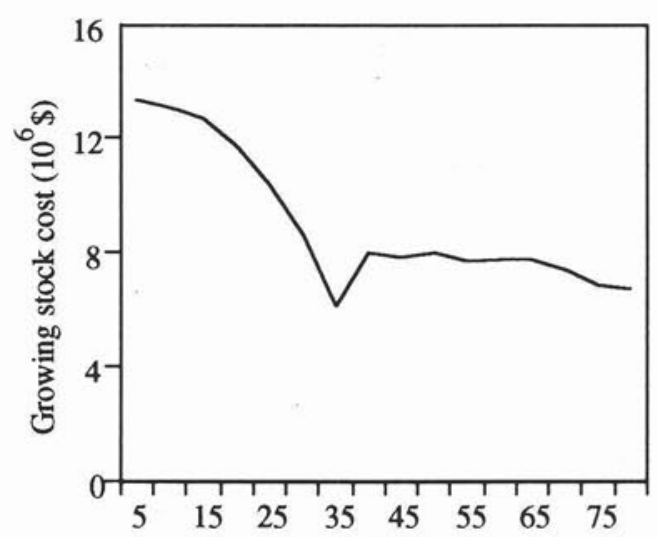

(c)

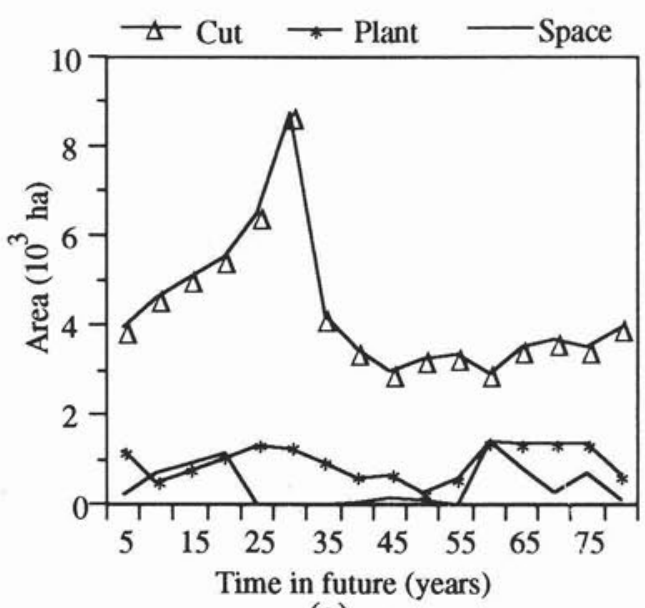

(e)

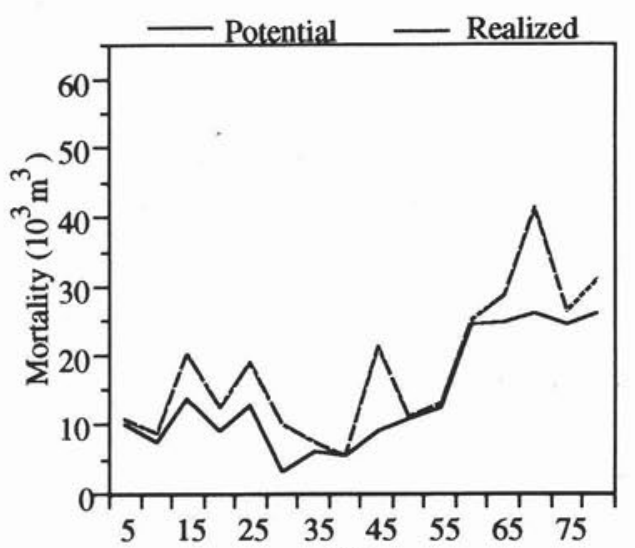

(b)

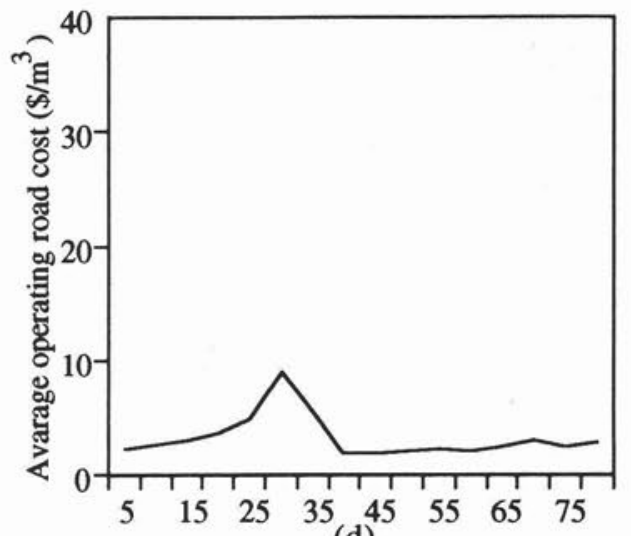

(d)

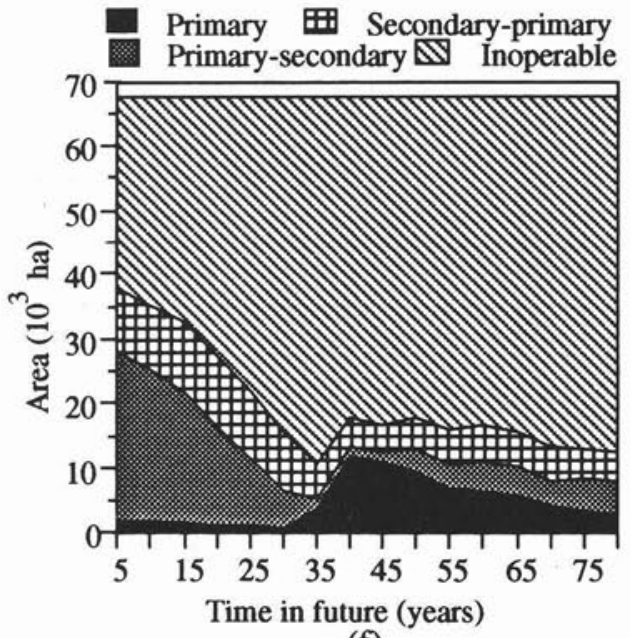

(f)

Figure 5. The results of Strategy 3 (minimize operating road cost, one period adjacency delay, maximum $\$ 15$ operating road cost limit). Sustained harvest level is $466000 \mathrm{~m}^{3} /$ period. The performance indicators are: (a) growing stock (b) mortality (c) growing stock cost (operating road) (d) average operating road cost (e) cut, planted and spaced area and (f) operable-inoperable area distribution.

where wood was cheap in terms of operating road cost, thus the strategies left expensive wood for the future (Fig. 3c, 4c, $5 \mathrm{c}$ and $6 \mathrm{c}$ ). Second, since the strategies did not target the old age classes for harvesting first, stands were allowed to grow into older age classes, and lose volume to mortality. Since
Strategies 2, 3, and 4 also included an extended adjacency delay, an operating road cost limit, and both, respectively, it is clear they caused even more volume mortality losses (compare Fig. 3b to Fig. $4 b, 5 b$ and $6 b$ ). This in turn decreased operable and effective growing stocks and increased growing stock cost. 


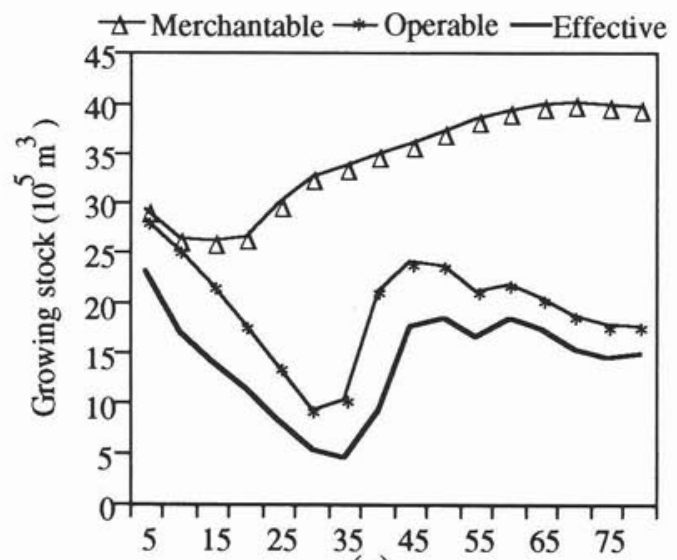

(a)

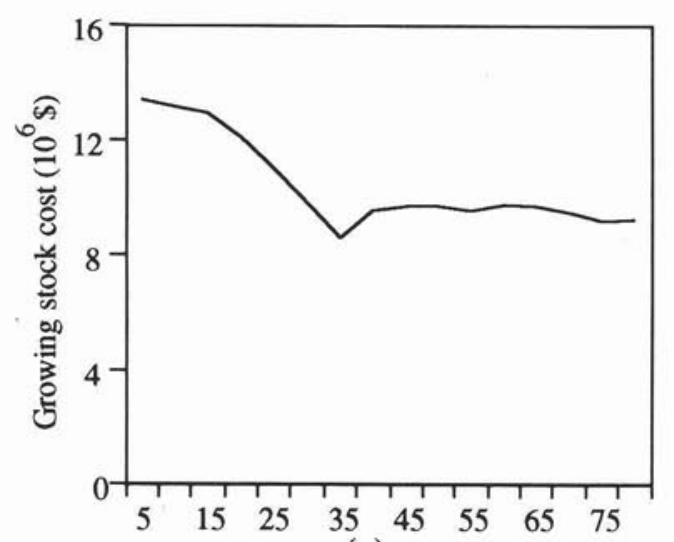

(c)

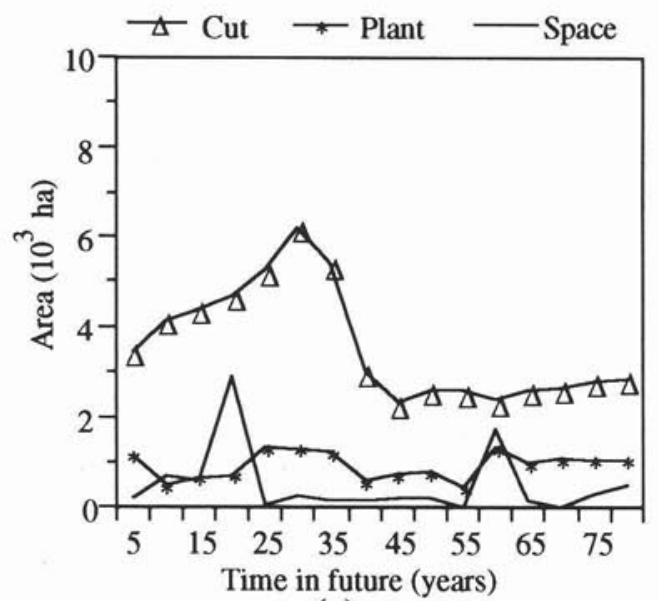

(e)

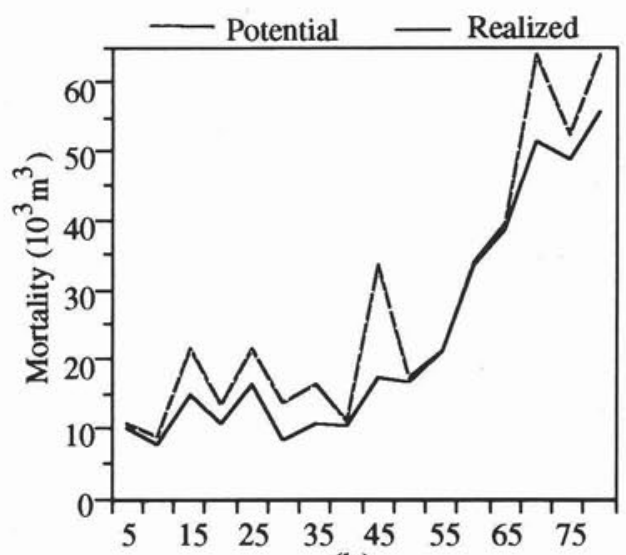

(b)
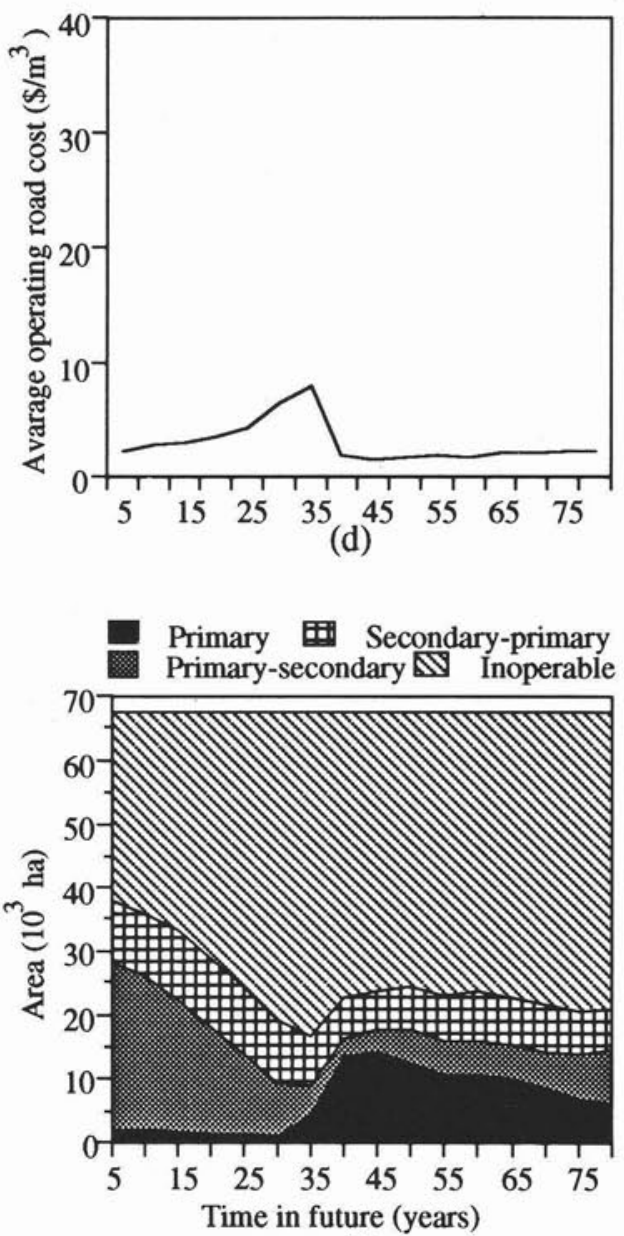

(f)

Figure 6. The results of Strategy 4 (minimize operating road cost, two period adjacency delay, maximum $\$ 15$ operating road cost limit). Sustained harvest level is $414000 \mathrm{~m}^{3} /$ period. The performance indicators are: (a) growing stock (b) mortality (c) growing stock cost (operating road) (d) average operating road cost (e) cut, planted and spaced area and (f) operable-inoperable area distribution.

\section{Minimizing Block Mortality Loss Effect}

Figure 7 shows results of Strategy 5, minimize mortality losses without an operating road cost limit. The maximum harvest level was $94000 \mathrm{~m}^{3} /$ year - a $7.8 \%$ reduction from the control level. Reasons used previously to explain the effect of its pair, Strategy 1, apply here as well; but, the reduction is $2.9 \%(7.8 \%-4.9 \%)$ larger because minimizing mortality losses harvested more area (than minimizing road cost) to meet a given harvest level since it targeted blocks of older stands that usually have less volume per hectare 


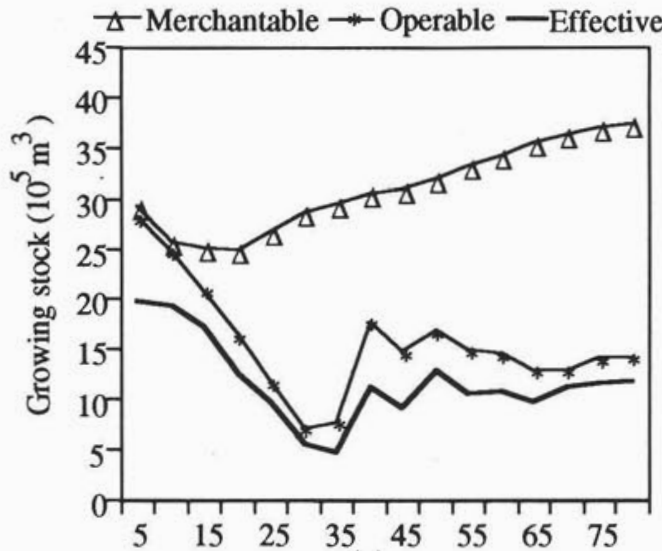

(a)

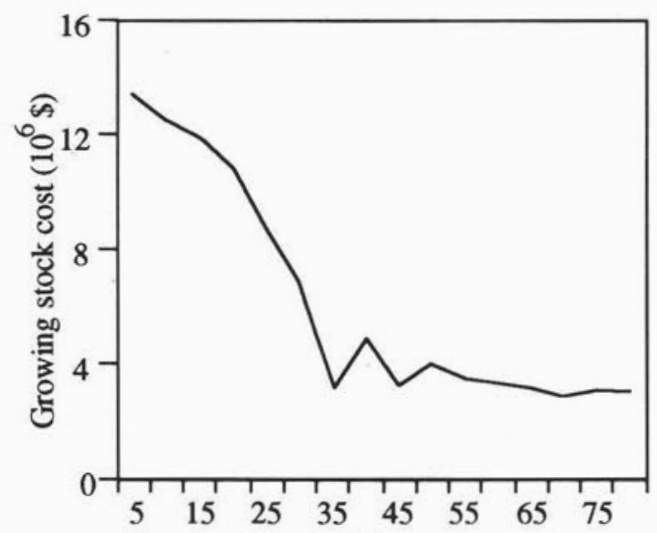

(c)

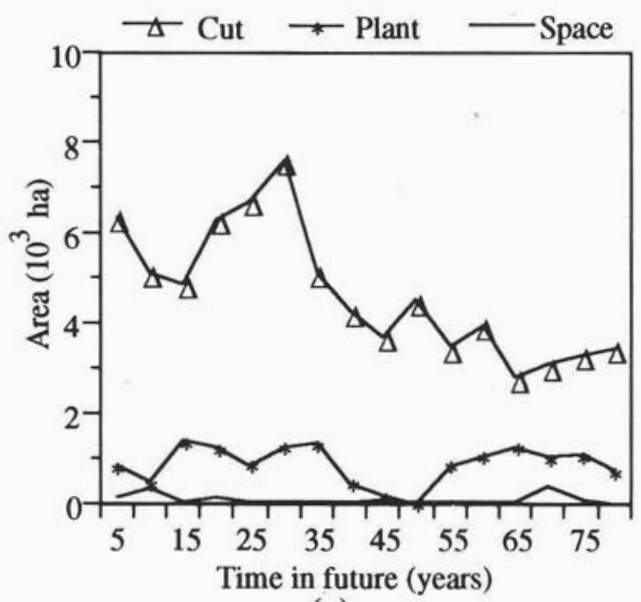

(e)

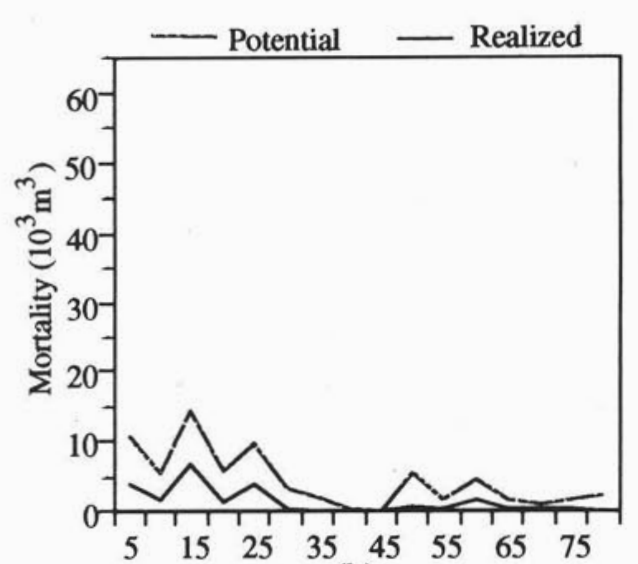

(b)

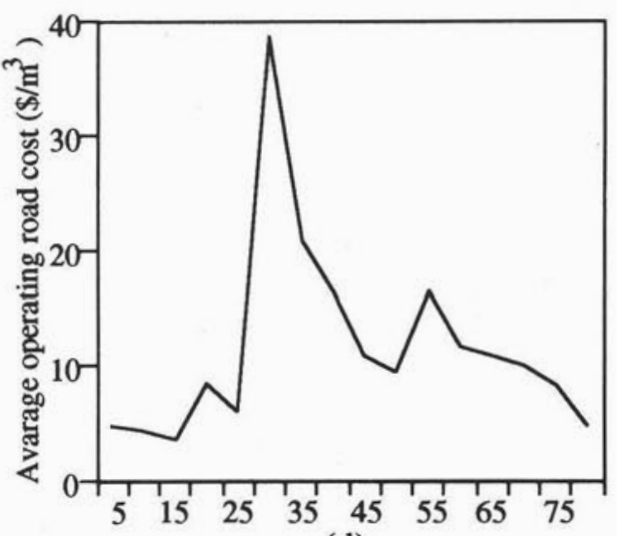

(d)

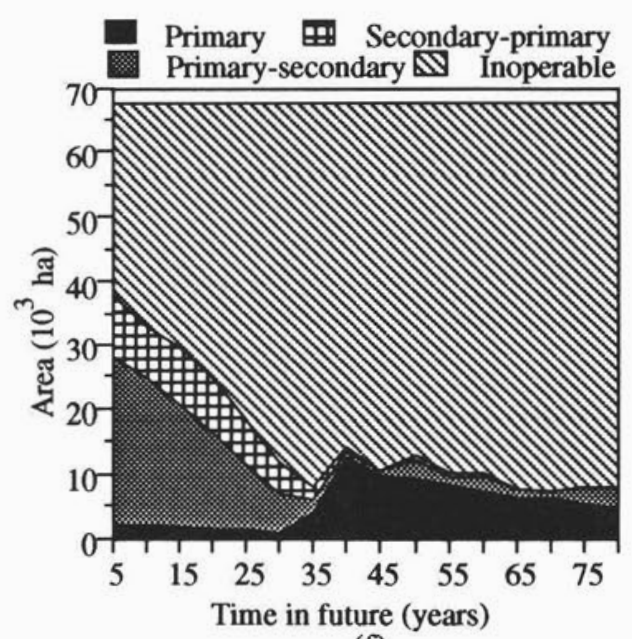

(f)

Figure 7. The results of Strategy 5 (minimize harvest block mortality, one period adjacency delay, no operating road cost limit). Sustained harvest level is $470000 \mathrm{~m}^{3} /$ period. The performance indicators are: (a) growing stock (b) mortality (c) growing stock cost (operating road) (d) average operating road cost (e) cut, planted and spaced area and (f) operable-inoperable area distribution.

(Figs. 3e and 7e). On the other hand, minimizing operating road cost tended to target blocks of stands that were at peak volume and as a result needed less area to meet a given harvest level. Consequently, by recycling more of the forest into regenerating and inoperable stages, Strategy 5 left fewer operable areas in later years when compared to Strategy 1 (Fig. 3e compared to Fig. 7e). The harvest blocking impact of minimizing mortality losses provides a further explanation of the lower harvest level. Minimizing mortality losses causes blocks of older stands to be cut first and does not 

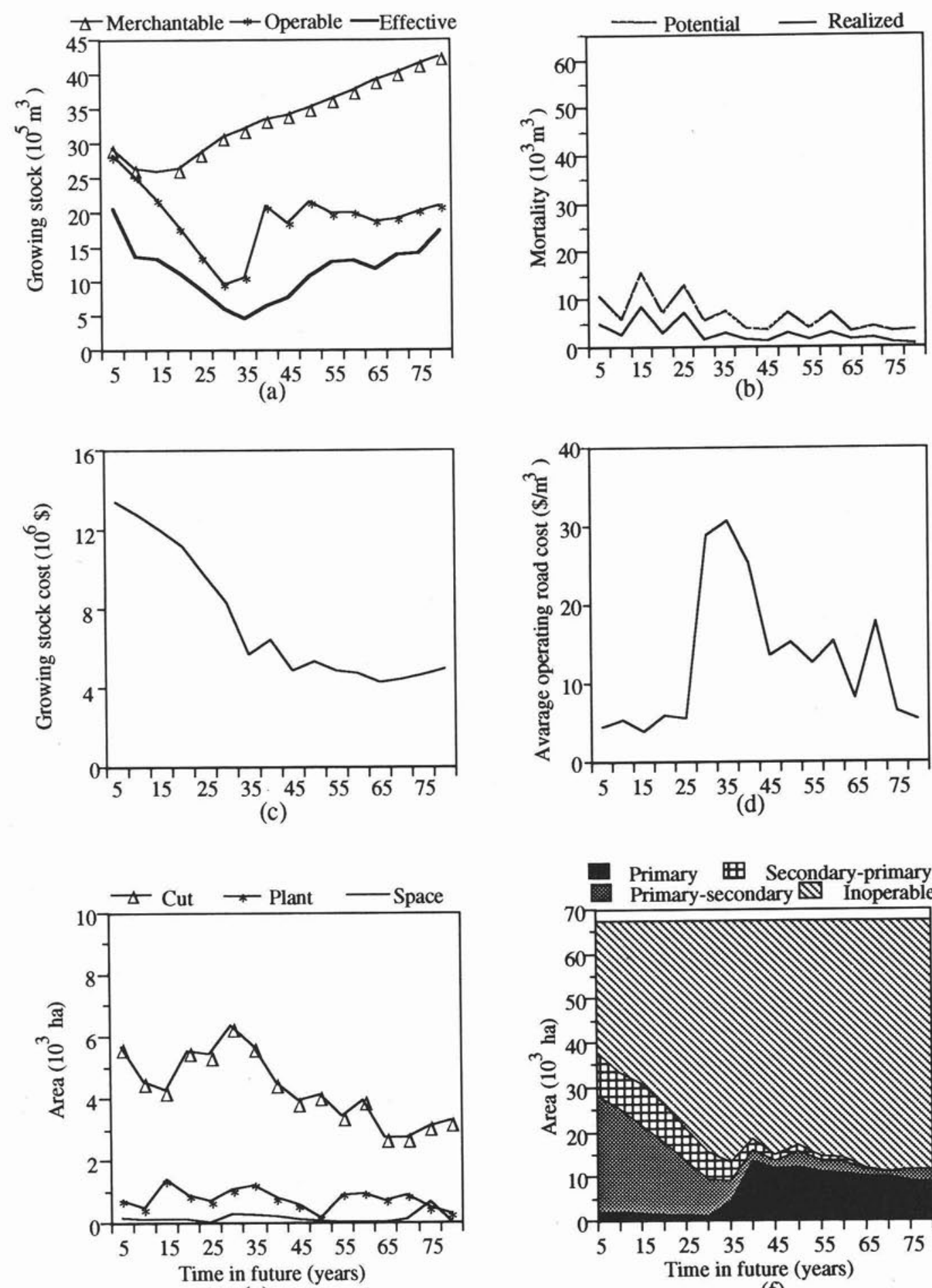

(e)

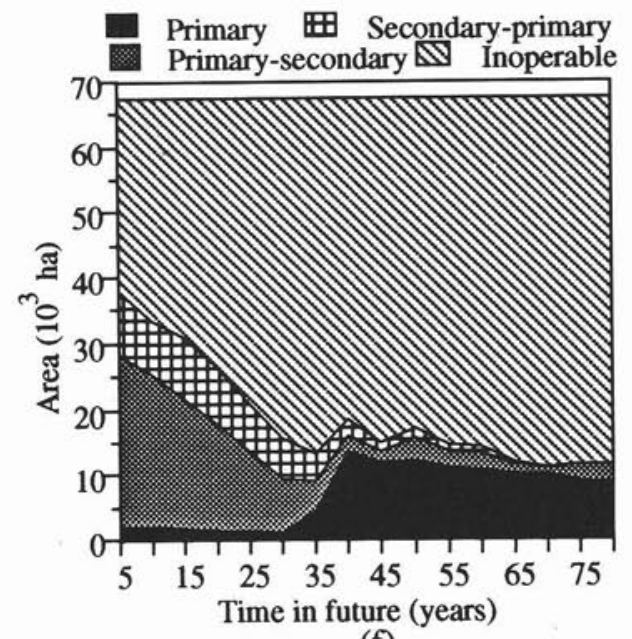

(f)

Figure 8. The results of Strategy 6 (minimize harvest block mortality, two period adjacency delay, no operating cost limit). Sustained harvest level is $420000 \mathrm{~m}^{3} /$ period. The performance indicators are: (a) growing stock (b) mortality (c) growing stock cost (operating road) (d) average operating road cost (e) cut, planted and spaced area and (f) operable-inoperable area distribution.

consider volume concentration. Minimizing operating road cost, in contrast, results in fewer harvest blocks since it targets blocks whose volume concentration is higher (large blocks, low operating road cost). With fewer cut blocks allocated, maximum block size and adjacency violations occur less frequently. More timber is available for harvesting and as a result, a higher harvest level is sustainable.

Strategy 6 , minimize mortality losses without an operating cost limit but with an extended adjacency delay, reduced the sustainable harvest level by $17.6 \%$ to $84000 \mathrm{~m}^{3} /$ year - 


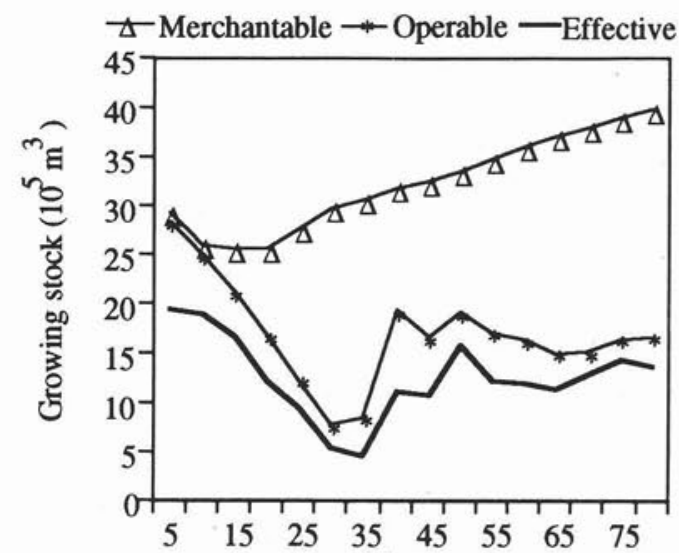

(a)

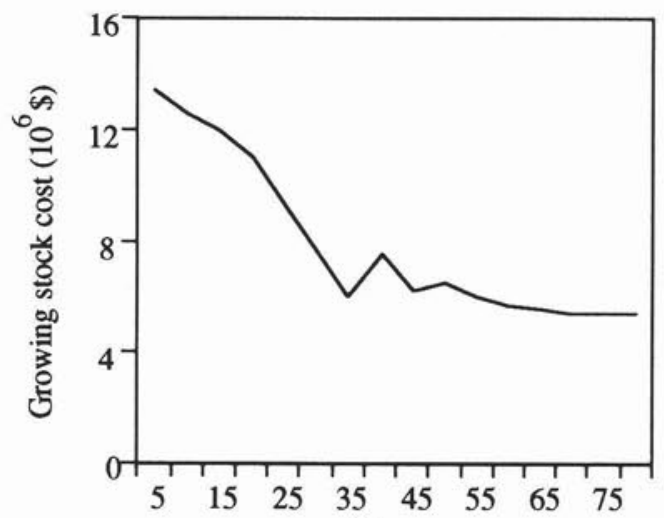

(c)

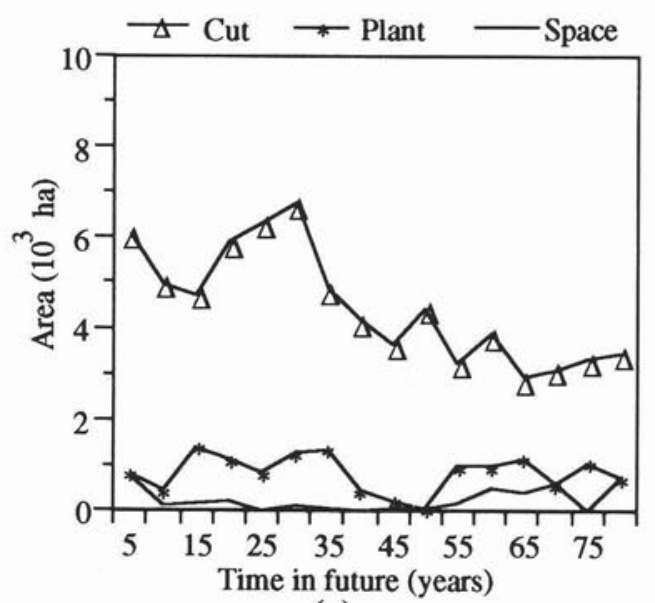

(e)

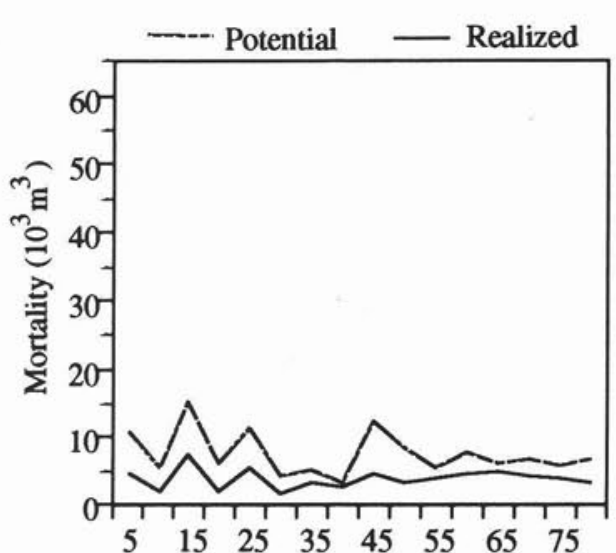

(b)

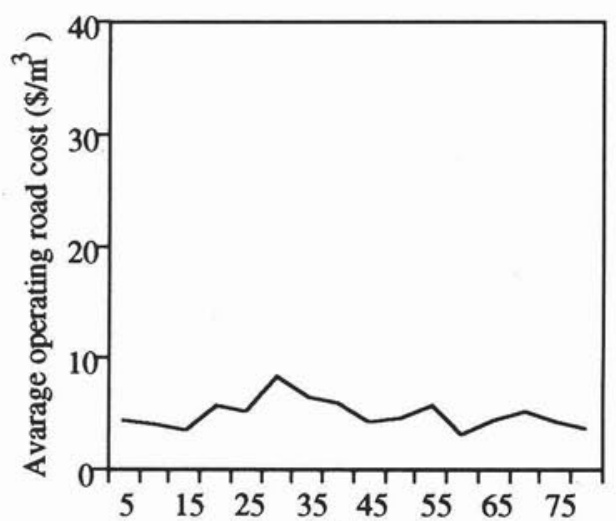

(d)

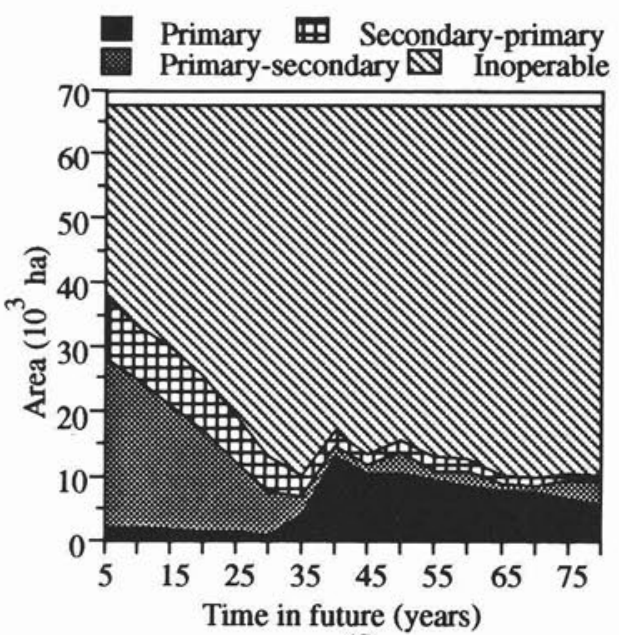

(f)

Figure 9. The results of Strategy 7 (minimize harvest block mortality, one period adjacency delay, maximum $\$ 15$ operating road cost limit). Sustained harvest level is $455000 \mathrm{~m}^{3} /$ period. The performance indicators are: (a) growing stock (b) mortality (c) growing stock cost (operating road) (d) average operating road cost (e) cut, planted and spaced area and (f) operable-inoperable area distribution.

an additional $9.8 \%(17.6 \%-7.8 \%)$ from Strategy 5 (Fig. 8). Besides the reasons provided for Strategy 5 , the additional $9.8 \%(17.6 \%-7.8 \%)$ reduction can be attributed to the extended adjacency delay as also explained for its pair, Strategy 2. The big differences between operable and effective growing stocks show that more harvest blocks were considered unavailable for harvesting during the simulation, resulting in a total $17.6 \%$ reduction in harvest level (Fig. 8a).

Strategy 7 , minimize mortality losses with a maximum $\$ 15$ operating road cost limit and an extended adjacency delay, 


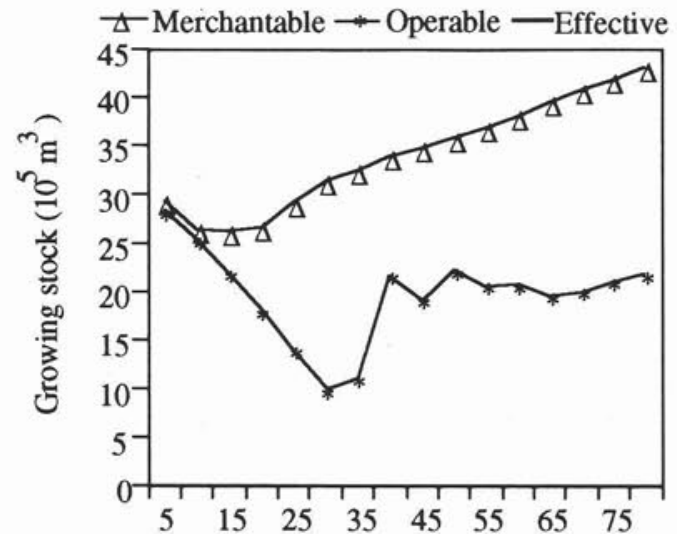

(a)

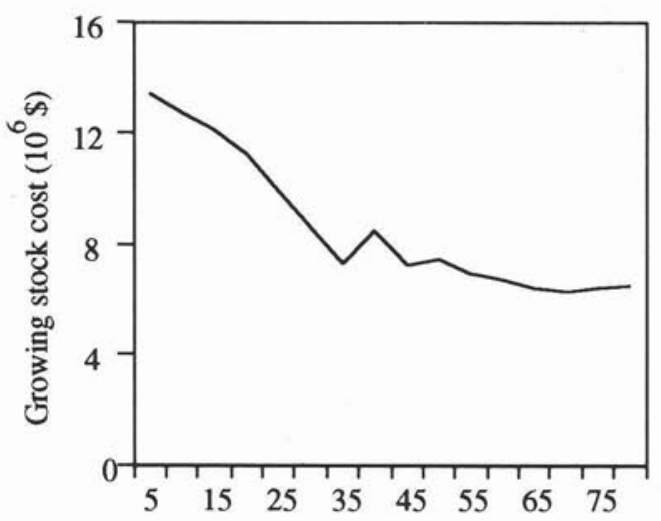

(c)

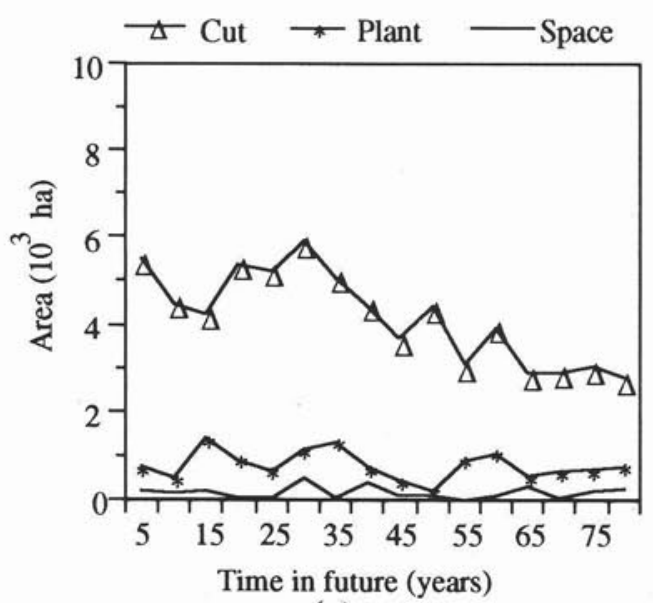

(e)

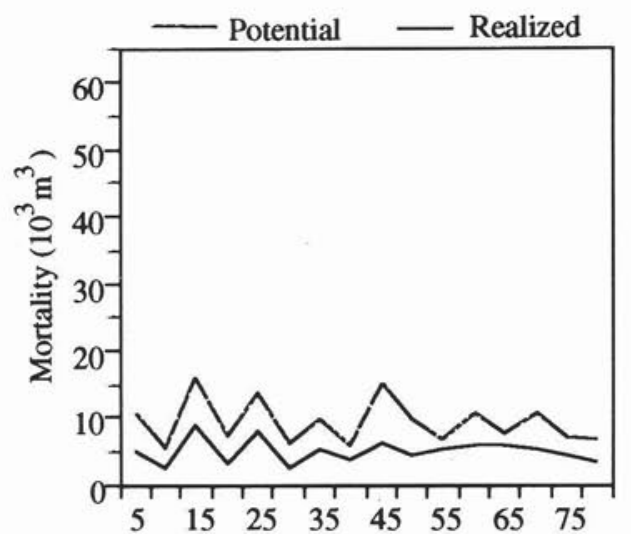

(b)

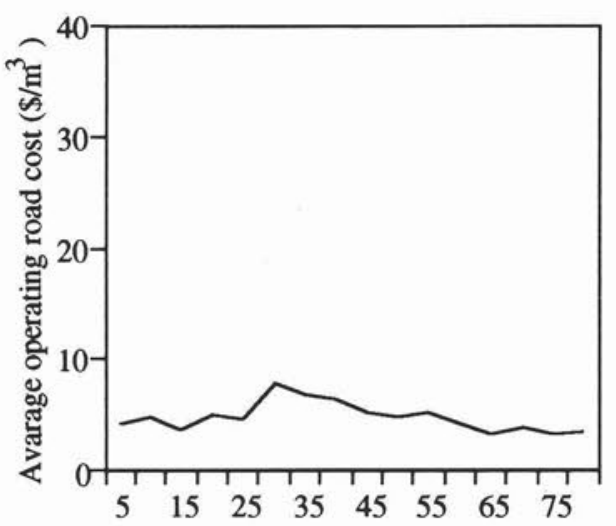

(d)

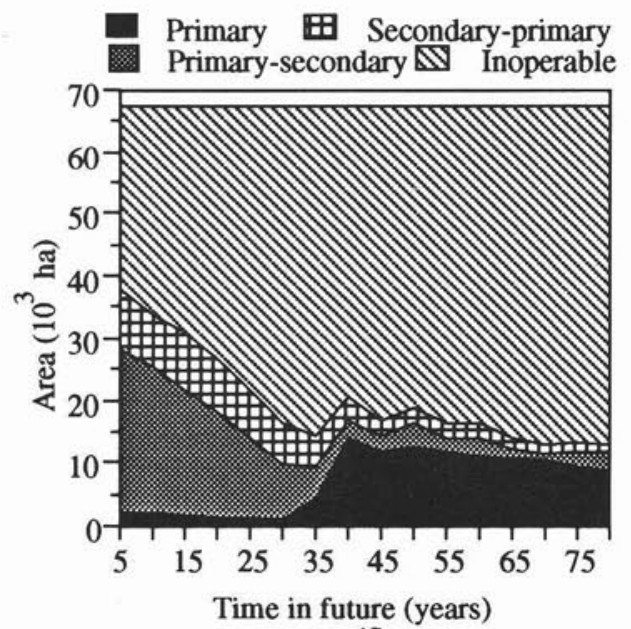

(f)

Figure 10. The results of Strategy 8 (minimize harvest block mortality, two period adjacency delay, maximum $\$ 15$ operating road cost limit). Sustained harvest level is $412000 \mathrm{~m}^{3} /$ period. The performance indicators are: (a) growing stock (b) mortality (c) growing stock cost (operating road) (d) average operating road cost (e) cut, planted and spaced area and (f) operable-inoperable area distribution.

reduced the sustainable harvest level by $10.7 \%$ to $91000 \mathrm{~m}^{3} /$ year - an additional $2.9 \%(10.7 \%-7.8 \%)$ from Strategy 5 (Fig. 9). Besides the reasons provided for Strategy 5, the additional reduction was due to the maximum $\$ 15$ operating road cost limit as also explained for its pair,
Strategy 3. Differences between operable and effective growing stocks (Fig. 9a) show that some harvest blocks exceeded the $\$ 15$ operating road cost limit and were considered unavailable for harvesting during the simulation, resulting in an additional $2.9 \%$ reduction in harvest level. 


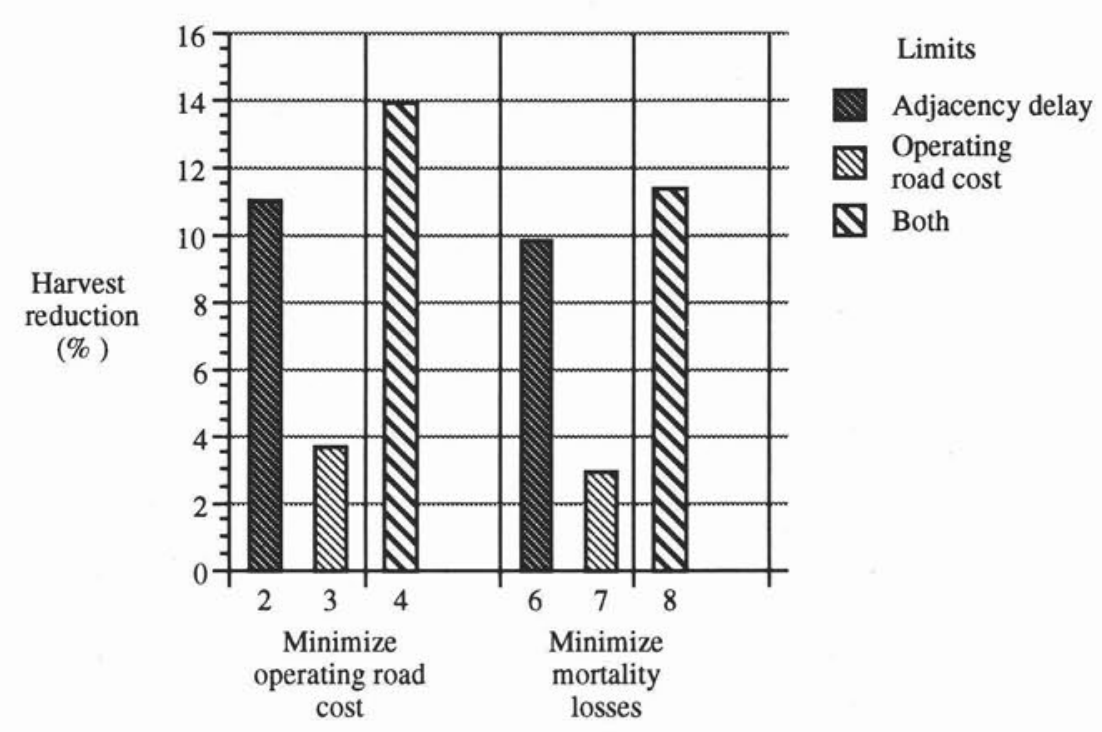

Figure 11. The effects of operating road cost and adjacency delay limits on sustainable harvest levels.

Strategy 8 , minimize mortality losses with a maximum operating road cost limit of $\$ 15$ and a two period adjacency delay, greatly reduced the harvest level by $19.2 \%$ to $82400 \mathrm{~m}^{3} /$ year. That is an additional $11.4 \%$ $(19.2 \%-7.8 \%)$ reduction from Strategy 5 (Fig. 10), the largest among the strategies tested. The main reason for this reduction, beyond the reasons provided for strategy 5 , is that Strategy 8 restricted blocks for harvest with both an extended adjacency delay and a maximum $\$ 15$ operating road cost limit as explained for its pair, Strategy 4 . The big difference between operable and effective growing stocks (Fig. 10a) shows that more volume was considered unavailable for harvesting because of these two constraints.

Performance indicators produced with Strategies 5 through 8 reflect the dynamics of the Canaan forest under management. The same trends, as in the first four strategies, for operable and effective growing stocks (Fig. 7a, 8a, 9a and 10a), average operating road cost (Fig. 7d, 8d, 9d and 10d), area cut (Fig. 7e, 8e, 9e and 10e) and operable area (Fig. 7f, $8 \mathrm{f}, 9 \mathrm{f}$ and $10 \mathrm{f})$ were observed. However, the growing stock costs (Fig. 7c, 8c, 9c, and 10c) were generally less, reflecting a difference in change in the geographic distribution of stand developmental types and stages over time and its effect on operating road cost. While the strategies that minimized mortality losses resulted in a forest characterized by a geographic distribution of stand developmental types and stages that produced geographically concentrated primary volumes, i.e. an inexpensive forest, the strategies that minimized operating road cost high-graded the forest and expensive, geographically-scattered primary volumes eventually resulted.

Strategies 5 through 8 lead to two common conclusions. First, these minimize mortality strategies mostly concentrated harvest in geographic areas where the forest was overmature, making the harvested wood expensive in terms of operating road cost. Second, since these strategies harvested old age classes first, stands tended not to reach overmaturity. Therefore, while harvesting blocks of older stands was successful in capturing volume loss to mortality (Fig. 7b, 8b,
$9 \mathrm{~b}$, and 10b), it geographically scattered the harvest; but, this ensured cheaper growing stock in the future.

\section{Operating Road Cost Limit and Adjacency Delay Effects}

When the effects of adjacency and operating road cost limits were isolated (Fig. 11), the strategies that minimized operating road cost $(6,7,8)$ produced consistently higher sustainable harvest level reductions when compared to the strategies that minimized mortality losses $(2,3,4)$. These limits are more constraining when minimize operating road cost strategies are involved. For example, the effect of extending adjacency delay to two periods in Strategy 6 is a 9.8\% reduction of sustainable harvest level $-1.2 \%$ less than Strategy 2 . The area cut during the critical years is less with Strategy 6 than that with Strategy 2 (compare Figure 8e to Figure 4e). This means that the possibility of adjacency violations is less than Strategy 2, resulting in lower reduction in sustainable harvest. The effect of the operating road cost limit is also different between the two strategy groupings. When Strategies 3 and 7 are compared, the later shows a $0.8 \%$ smaller reduction in sustainable harvest level. Strategy 7 harvested blocks losing volume to mortality before they exceeded the $\$ 15$ operating road cost limit, while Strategy 3 didn't priorize blocks losing volume to mortality and eventually more blocks exceeding the $\$ 15$ operating road cost limit appeared.

\section{General Observations}

Results of strategies tested showed that some significant differences in the dynamics of the forest exist in response to management strategies that minimized mortality losses and those that minimized operating road cost. First, strategies that minimized operating road cost left the forest with declining operable and effective growing stocks since it harvested the best stands first. More areas became overmature and inoperable before they were harvested. High mortality losses occurred and operable and effective volume decreased after 35 years. Strategies that minimized mortality losses, 
however, harvested older areas first and after 35 years, the unharvested young areas became available. Therefore, the operable and effective growing stocks increased, while mortality decreased. Additionally, since strategies that minimized operating road cost targeted high primary volume areas, they harvested fewer hectares, while strategies that minimized mortality losses left areas with high primary volumes. Therefore, minimizing operating road cost left the forest with more stands dominated by secondary volume, whereas minimizing mortality losses left the forest with stands mostly dominated by primary volume (compare Fig. 3f, 4f, 5f, $6 \mathrm{f}$ to Fig. $7 \mathrm{f}$, $8 \mathrm{f}, 9 \mathrm{f}, 10 \mathrm{f})$.

\section{Conclusion}

The way that operable wood quantities are geographically located, relative to one another, determines their availability for harvest. The geographic structure of a forest and its change over time, therefore, is an important determinant of wood supply. Wood supply is limited to those operable timber quantities that are both economically extractable and not required to maintain wildlife habitat. However, conventional wood supply models lack any consideration of geographic forest structure necessary to include economics and wildlife in the forecasting process. They provide, in fact, an overestimate of sustainable wood supply. This study has, for one test forest, measured the extent of the error and attempted to explain results in light of forest dynamics.

Spatial models, like GISFORMAN, open the opportunity to deal simultaneously with operationally important economic and wildlife issues, and to quantify any tradeoffs in wood supply analysis. The ability to translate management strategies into operational mapped schedules further increases appeal.

\section{Acknowledgements}

This study was funded by the Turkish Government through Karadeniz Technical University, Trabzon. The Faculty of Forestry at the University of New Brunswick provided the computer hardware and software facilities through NSERC grant FRD0041017.

\section{Literature Cited}

Baskent, E. Z. 1990. Spatial wood supply modelling: concept and practice. Unpublished MScF thesis. Faculty of Forestry, Univ. of New Brunswick, Fredericton, NB. ix +85 p.

Baskent, E.Z. and G.A. Jordan. 1990. Spatial wood supply simulation modelling. The Forestry Chronicle: Dec. 1991.

Baskerville, G.L. 1978. Forest dynamics and management decisions. Univ. of New Brunswick, Faculty of Forestry, Fredericton, N.B. 73 p.

Baskerville, G.L. 1982. Strategic planning in the transition to forest management. (pp. 17-20). Can. Pulp \& Pap. Assoc. 63.

Clifford, W.L.T. 1981. Wood supply analysis by simulation. Unpublished MScF thesis. Faculty of Forestry, Univ. of New Brunswick, Fredericton, NB. 98 p.

Hall, T.H. 1978. Toward a framework for forest management decision-making in New Brunswick. TR-78. NB Dept. of Nat. Res., Fredericton, NB. 83 p.

Hall, T.H. 1981. Forest management decision-making: art or science? (pp. 233-238). The Forestry Chronicle: 57.

Wang, C.E., T.A. Erdle and T. Roussell. 1987. User Manual: FORMAN wood supply model. Fredericton: New Brunswick Executive Forest Research Committee Inc., 61 p.
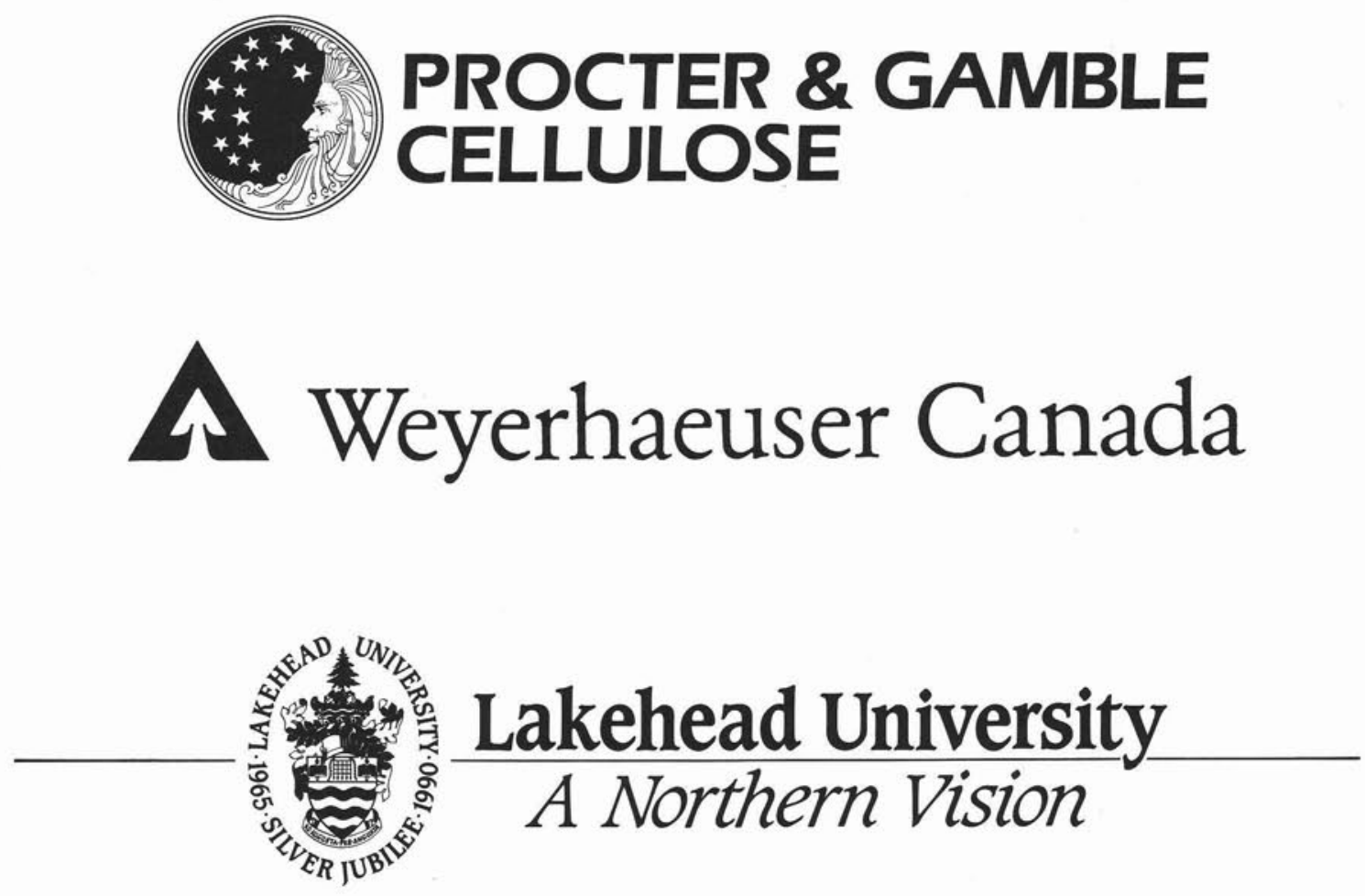

CIF/IFC Corporate Sustaining Members 